\title{
Effect of carbon dioxide on the survival of ram spermatozoa frozen by the pellet method
}

\author{
Yutaka Fukuı* and E. M. RoBerts \\ School of Wool and Pastoral Sciences, The University of New South Wales, \\ Kensington, N.S.W., 2033 Australia
}

\begin{abstract}
Summary. Two experiments were conducted to examine the effect of carbon dioxide $\left(\mathrm{CO}_{2}\right.$ gas) on the survival of ram spermatozoa frozen by the pellet method. Frozen-thawed semen was flushed with $\mathrm{CO}_{2}$ gas for various periods and the motility of spermatozoa after thawing was investigated. The longer periods for more than 135 seconds of $\mathrm{CO}_{2}$ gas treatment significantly $(P<0.01)$ depressed the motility of spermatozoa after thawing. However, flushing with $\mathrm{CO}_{2}$ gas for less than 90 seconds did not affect the motility. It appears that flushing with $\mathrm{CO}_{2}$ gas for a limited time, 90 seconds at the time of insemination could be effectively utilized for the rapid method of non-surgical intrauterine insemination with frozen-thawed semen in sheep.
\end{abstract}

(Japan. J. Amim. Reprod., 28, 212-216, 1982)

\section{Introduction}

A satisfactory recovery of frozen ram spermatozoa has been obtained. However, fertility of frozen-thawed ram semen has not been good as in the frozen bull spermatozoa, although many workers have reported lambing rates of $55-68 \%{ }^{1-5}$. It seems to be that the site of deposition of semen is one of the major factor which affects conception rate following insemination, especially in the ewe. The cervix in the ewe is characteristic due to its great length $(4-10 \mathrm{~cm})$ and the complexity of its lumen ${ }^{6-3)}$. Therefore, it has been generally agreed that the site of semen deposition in the ewe is usually at the external orifice of the cervical canal.

Since Andersen et al. ${ }^{2)}$ demonstrated a technique for non-surgical intrauterine insemination in ewes, FukuI and Roberts ${ }^{9-13)}$ have

* Present address: Department of Meat Animal Reproduction, Obihiro University of Agriculture and Veterinary Medicine, Obihiro, 080 Japan. investigated the effect of non-surgical intrauterine insemination with frozen ram semen on the conception rate. Fukui ${ }^{14)}$ and FuKuI and Roberts ${ }^{13)}$ indicated from their experiments that the use of $\mathrm{CO}_{2}$ gas could be effective for the conventional and rapid method of non-surgical intrauterine insemination in ewes. It is reasonably understood that semen can be forced into the uterus by the pressure of $\mathrm{CO}_{2}$ gas from as near the external orifice of the cervical canal. This would be a rapid method of deposition due to the removal of the necessity to penetrate the whole length of the cervical canal.

Since MAKISIMov ${ }^{15,16)}$ reported that $\mathrm{CO}_{2}$ gas was not harmful to sperm cells, $\mathrm{CO}_{2}$ gas has been widely used for preservation of $\mathrm{ram}^{17}$, bull ${ }^{18)}$ and human spermatozoa (Climie, C. R., 1975, personal communications). In these reports, $\mathrm{CO}_{2}$ gas has been used as a component of diluents. Therefore, it should be be investigated the effect of $\mathrm{CO}_{2}$ gas on the motility of frozen ram spermatozoa and the period of flushing $\mathrm{CO}_{2}$ gas for its application 
to non-surgical intrauterine insemination. Because the method of flushing with $\mathrm{CO}_{2}$ gas is somewhat different from those have been adopted in the previous paper. In our technique, $\mathrm{CO}_{2}$ gas is flushed at the time of insemination after thawing of frozen spermatozoa and they are exposed for considerably long periods.

\section{Materials and Methods}

Two experiments were conducted. Semen was collected from two mature Merino and Border Leicester rams using an artificial vagina. Aliquiots of semen were diluted with an extender, Tris (hydroxymethyl) aminomethane (300 $\mathrm{mm})$-glucose $(27.75 \mathrm{~mm})$-egg yolk $(15 \% \mathrm{v} / \mathrm{v})$-glycerol $(5 \% \mathrm{v} / \mathrm{v})$ and frozen in pellet form according to the method described by Fukui ${ }^{19)}$. Frozen pelleted semen were thawed in dry and clean test tubes $(2.5 \mathrm{~cm}$ in the outer diameter) at $37^{\circ} \mathrm{C}$ without thawing solution. The thawed semen in the test tube was flushed $\mathrm{CO}_{2}$ gas for various periods (see Experiments 1 and 2) using a modified 13 gauge needle connected with an inseminating pipette (Fig. 1). The $\mathrm{CO}_{2}$ gas was flowed with a rate of $2 \mathrm{l} / \mathrm{min}$ at $40 \mathrm{~cm}$ in water level. The flushed semen was then maintained at $37^{\circ} \mathrm{C}$ in a water bath. The percentage of motile

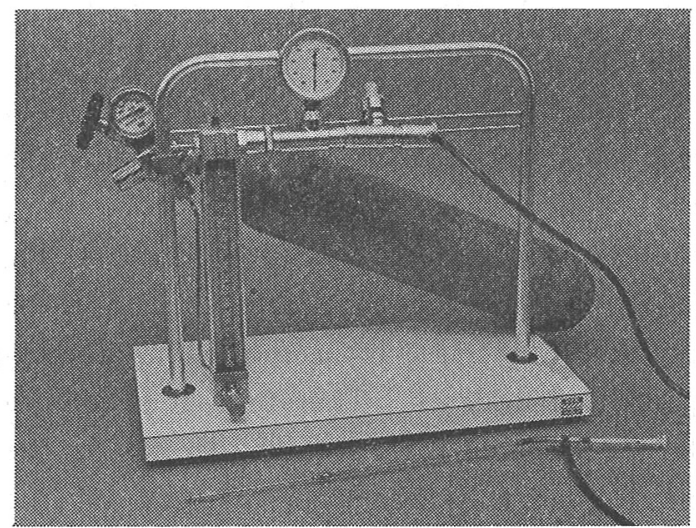

Fig. 1. An instrument for supplying $\mathrm{CO}_{2}$ gas. spermatozoa assessed under a coverslip on an warm stage $\left(37^{\circ} \mathrm{C}\right)$ immedieately after thawing, and at the intervals of 2 hours during subsequent incubation up to 6 hours.

Experiment 1: The experiment was designed as follows;

1) Breeds of rams: Merino v. Border Leicester

2) Replicates: a v. b v. c

3) Periods of $\mathrm{CO}_{2}$ gas treatment (sec): $0 \mathrm{v}$. 45 v. 90 v. 135 v. 180 v. 225 v. 270

4) Incubation (hr): 0 v. 2 v. 4 v. 6

Experiment 2: The experiment was conducted to investigate the effect of $\mathrm{CO}_{2}$ gas treatment for more rigorous periods on the motility of ram spermatozoa. Factors investigated in the design were as follows;

2) Breeds of rams: Merino v. Border Leicester

2) Replicates: a v. b v. c

3) Periods of $\mathrm{CO}_{2}$ gas treatment (sec): $0 \mathrm{v}$. 22.5 v. 45 v. 67.5 v. 90

4) Incubation (hr): 0 v. 2 v. 4 v. 6

Table 1. Analysis of variance for the data of Experiment 1

\begin{tabular}{lrrc}
\hline \multicolumn{1}{c}{$\begin{array}{c}\text { Source of } \\
\text { variation }\end{array}$} & D.F. & M.S. & $\mathrm{F}$ \\
\hline Breeds of rams (A) & 1 & 108.20 & 3.74 \\
Replicates (B) & 2 & 124.82 & $4.32^{*}$ \\
Periods of $\mathrm{CO}_{2}$ gas & 6 & 454.25 & $15,70^{* * *}$ \\
$\quad$ treatment (C) & & & \\
Incubation (D) & 3 & 3131.73 & $157.71^{* * *}$ \\
$\mathrm{~A} \times \mathrm{B}$ & 2 & 109.53 & 3.79 \\
$\mathrm{~A} \times \mathrm{C}$ & 6 & 94.76 & $3.28^{*}$ \\
$\mathrm{~A} \times \mathrm{D}$ & 3 & 149.66 & $7.54^{* *}$ \\
$\mathrm{~B} \times \mathrm{C}$ & 12 & 70.29 & 2.43 \\
$\mathrm{~B} \times \mathrm{D}$ & 6 & 70.98 & $3.57^{*}$ \\
$\mathrm{C} \times \mathrm{D}$ & 18 & 40.95 & 2.06 \\
$\mathrm{~A} \times \mathrm{B} \times \mathrm{C}$ & 12 & 28.93 & 1.00 \\
$\mathrm{~A} \times \mathrm{B} \times \mathrm{D}$ & 6 & 49.07 & 2.47 \\
$\mathrm{~A} \times \mathrm{C} \times \mathrm{D}$ & 18 & 28.81 & 1.45 \\
$\mathrm{~B} \times \mathrm{C} \times \mathrm{D}$ & 36 & 12.79 & 0.64 \\
$\mathrm{E} r \mathrm{ror}$ & 36 & 19.86 & \\
\hline$* P<0.05, * * P<0.01, * * *$ & $P<0.001$. & \\
\hline
\end{tabular}


Table 2. Effect of $\mathrm{CO}_{2}$ gas treatment on the mean percentage of motile spermotozoa during post-thawing incubation at $37^{\circ} \mathrm{C}$ (Experiment 1$)$

\begin{tabular}{lcccccccc}
\hline \hline \multirow{2}{*}{$\begin{array}{c}\text { Breeds of } \\
\text { rams }\end{array}$} & \multicolumn{7}{c}{$\begin{array}{c}\text { Motile spermatozoa (\%) following various } \\
\text { periods of } \mathrm{CO}_{2} \text { gas treatment (sec) }\end{array}$} \\
\cline { 2 - 7 } & 0 & 45 & 90 & 135 & 180 & 225 & 270 & Means \\
\hline Merino & 30.3 & 33.5 & 33.5 & 29.8 & 26.3 & 25.0 & 20.6 & 28.3 \\
$\begin{array}{l}\text { Border } \\
\quad \text { Leicester }\end{array}$ & 42.0 & 38.6 & 32.8 & 33.4 & 24.9 & 33.1 & 14.3 & 30.9 \\
\hline Means & 36.0 & 36.0 & 33.2 & 31.6 & 25.6 & 28.9 & 17.4 & 29.6 \\
\hline
\end{tabular}

Table 3. Analysis of variance for the data of Experiment 2

\begin{tabular}{lrrc}
\hline \hline \multicolumn{1}{c}{$\begin{array}{c}\text { Source of } \\
\text { variation }\end{array}$} & D.F. & M.S. & $\mathrm{F}$ \\
\hline Breeds of rams (A) & 1 & 9.75 & 1.10 \\
Replicates (B) & 2 & 25.73 & 2.91 \\
Periods of $\mathrm{CO}_{2}$ gas & 4 & 31.69 & 3.58 \\
$\quad$ treatment (C) & & & \\
Incubation (D) & 3 & 1362.52 & $229.88^{* * *}$ \\
$\mathrm{~A} \times \mathrm{B}$ & 3 & 58.04 & $6.56^{*}$ \\
$\mathrm{~A} \times \mathrm{C}$ & 4 & 20.50 & 2.32 \\
$\mathrm{~A} \times \mathrm{D}$ & 3 & 55.32 & $9.33^{* *}$ \\
$\mathrm{~B} \times \mathrm{C}$ & 8 & 44.30 & $5.00^{*}$ \\
$\mathrm{~B} \times \mathrm{D}$ & 6 & 15.71 & 2.65 \\
$\mathrm{C} \times \mathrm{D}$ & 12 & 15.47 & 2.61 \\
$\mathrm{~A} \times \mathrm{B} \times \mathrm{C}$ & 8 & 8.85 & 1.00 \\
$\mathrm{~A} \times \mathrm{B} \times \mathrm{D}$ & 6 & 20.81 & 3.51 \\
$\mathrm{~A} \times \mathrm{C} \times \mathrm{D}$ & 12 & 15.52 & 2.62 \\
$\mathrm{~B} \times \mathrm{C} \times \mathrm{D}$ & 24 & 9.58 & 1.65 \\
$\mathrm{E} r \mathrm{r} r$ & 24 & 5.93 & \\
\hline$* \quad P<0.05, * * P<0.01, * * *$ & $P<0.001$. & \\
\end{tabular}

Table 4. Effect of $\mathrm{CO}_{2}$ gas treatment on the mean percentage of motile spermatozoa during post-thawing incubation using three replicates (Experiment 2)

\begin{tabular}{ccccc}
\hline \hline $\begin{array}{c}\text { Periods of } \\
\mathrm{CO}_{2} \text { gas } \\
\text { treatment } \\
(\mathrm{sec})\end{array}$ & \multicolumn{4}{c}{$\begin{array}{c}\text { Motile spermatozoa }(\%) \\
\text { following three replicates } \\
\text { of the sample }\end{array}$} \\
\cline { 2 - 5 } & $\mathrm{a}$ & $\mathrm{b}$ & $\mathrm{c}$ & Means \\
\hline 0 & 38.0 & 34.2 & 41.7 & 37.9 \\
22.5 & 38.3 & 39.9 & 33.2 & 37.1 \\
45.0 & 37.3 & 36.6 & 34.2 & 36.0 \\
67.5 & 33.6 & 40.5 & 38.4 & 37.5 \\
90.0 & 27.2 & 35.3 & 37.2 & 33.2 \\
\hline Means & 34.8 & 37.3 & 36.9 & 36.3 \\
\hline
\end{tabular}

The data were put into the computer programms for analysis of variance in both experiments.

\section{Results}

Experiment 1: The results of analysis of variance are shown in Table 1 . There were highly significant differences in the motility of ram spermatozoa after thawing among the periods of $\mathrm{CO}_{2}$ treatment $(P<0.001)$ and among the incubation periods after thawing $(P<$ 0.001). A significant difference was also found in the replicates $(P<0.05)$. There were significant interactions between the breed of rams and the periods of $\mathrm{CO}_{2}$ gas treatment $(P<0.05)$, between the breed of rams and the incubation periods $(P<0.01)$, and between the replicates and the incubation periods $(P<$ 0.05). Table 2 shows the results of the mean percentage of motility of spermatozoa after various periods of $\mathrm{CO}_{2}$ gas treatment in 2 breeds of rams. The longer periods for more than 135 seconds of $\mathrm{CO}_{2}$ gas treatment significantly $(P<0.01)$ depressed the motility of spermatozoa during the incubation at $37^{\circ} \mathrm{C}$ after thawing.

Experiment 2: The analysis of variance showing in Table 3 indicates that $\mathrm{CO}_{2}$ gas treatment for less than 90 second did not significantly affect the motility of spermatozoa after thawing, although there were 
significant interactions in 3 combinations between the breed of rams and the replicates, between the breed of rams and the incubation periods, and between the replicates and the periods of $\mathrm{CO}_{2}$ gas treatment. Table 4 shows interrelationship between the periods of $\mathrm{CO}_{2}$ gas treatment and the replicates in the motility of spermatozoa after thawing. The means of the post-thawing motility slightly declined with three replicates $(P<0.05)$, although it was found no significant differences in the motility of spermatozoa after thawing with either the $\mathrm{CO}_{2}$ gas treatment or the replicates (Table 3 ).

\section{Discussion}

Although Makisimov ${ }^{15,16)}$ reported that $\mathrm{CO}_{2}$ gas was not harmful to sperm cells, it is important to determine the period of $\mathrm{CO}_{2}$ gas treatment on its application for nonsurgical intrauterine insemination in sheep. The present experiments indicates that $\mathrm{CO}_{2}$ gas treatment for less than 90 seconds was not harmful to the motility of ram spermatozoa by the pellet method. In the study of Fukui and Roberts ${ }^{13)}$ in situ in the reproductive tract of ewes, $\mathrm{CO}_{2}$ gas or dye was forced into the uterine lumen for 10 to 30 seconds in almost all cases. At the present time the techniques on non-surgical intrauterine insemination are somewhat time-consuming taking several minutes ${ }^{2,12-14}$. The results obtained at the present experiments suggested that flushing with $\mathrm{CO}_{2}$ gas for a limited time, 90 seconds at the time of insemination could be effectively used for the conventional intrauterine insemination in sheep without loss of the motility of spermatozoa.

Acknowledgements The authors with to thank Dr. S. Salamon, University of Sydney, Australia for advice on techniques of deep freezing ram semen, and Mr. R. F. Scott for assistance in computer programming for analysis of the data.

\section{References}

1) Colas, G. \& G. Brice: Ann. Zootech., 19, 353, 1970.

2) Andersen, K., J. Aamdal \& J. A. Fougner: Zuchthygiene, 8, 113, 1973.

3) Visser, D. \& S. Salamon: Aust. J. Biol. Sci., 26, 513, 1973.

4) Colas, G.: J. Reprod. Fert., 42, 277, 1975.

5) Salamon, S.: Proc. 8th Int. Congr. Anim. Reprod. \& A.I. Krakow, 4, 1069, 1976.

6) Grant, R.: Trans. Roy. Soc. Edinb., 58, 1, 1933

7) Gunn, R. M. C.: Bull Coun. Sci. Indust. Res. Aust., 94, 105, 1936.

8) Dunn, R. B.: Aust. Vet. J., 31, 101, 1955.

9) Fukui, Y. \& E. M. Roberts: Proc. 8th Int. Congr. Anim. Reprod. \& A.I. Krakow, 4, 991, 1976.

10) Fukui, Y. \& E. M. Roberts: Proc. Int. Congr. Sheep Breed. Muresk \& Perth, pp. 482, 1976.

11) Fukui, Y. \& E. M. Roberts: J. Reprod. Fert., 51, 141, 1977.

12) Fukui, Y. \& E. M. Roberts: Theriogenology, 8, 77, 1977.

13) Fukui, Y. \& E. M. Roberts: Theriogenology, 10, 381, 1978.

14) Fukur, Y.: Ph. D. Thesis, The University of New South Wales, Australia, 1976.

15) Maкisimov, Ju. L.: Ovcevodstvo 5, 22, 1959, (Anim. Breed. Abstr., 27, 429, 1959).

16) Maкisimov, Ju. L.: Veterinari ja, 37, 81, 1960 (Anim. Breed. Abstr. 29, 184, 1961).

17) Dzabrailov, D, M. \& I. I. Sel'kin: Ovcevodstvo, 8, 29, 1962 (Anim. Breed. Abstr. 31, 80, 1963).

18) Salisbury, G. W. \& N. L. Van Demark: Nature, 180, 980, 1957.

19) Fukui, Y.: Jpn. J. Anim. Reprod., 25, 160, 1979.

(Received July 5, 1982) 


\title{
メンヨウ凍結精液に打ける融解後の精子生存性 に対する炭酸ガスの影響
}

\author{
福 井 豊*.E.M. ROBERTS \\ (ニュー・サウス・ウェールズ大学, 羊毛・牧畜学科, オース \\ トラリア：*現所属：帯広畜産大学畜産学部肉畜增殖学教室)
}

Fukui (1976), Fukui \& Roberts (1978) はメンヨウ の凍結精液による非外科的子宮内授精について検討し, 炭酸ガスを用いてより迅速な方法を提唱し, その有効性 を示唆した。本研究では, 上記術式の実用化に際して問 題になると考えられるメンヨウ錠剂凍結精液における融 解後の精子生存性に対する炭酸ガスの影響, および炭酸 ガスの処理時間について検討したので報告する。

実験方法は, 2 頭のメンヨウ (メリノー種, ボーダ 一・レセスター種) から人工胵で精液採取し, トリス $(300 \mathrm{~mm})$-グルコース $(27.75 \mathrm{~mm})$-卵黄 $(15 \%)$-グリセ リン $(5 \%)$ の希釈液で 5 倍希勫した。冷却抢よび錠剤凍 結法は従来の方法によった。 $37^{\circ} \mathrm{C}$ で融解後, 試験管内
に $2 \mathrm{l} /$ 分で種々の時間（実験 $1: 0 ， 45,90,135,180$, 225 そして 270 秒間, 実験 $2: 0,22.5,45,67.5$ そし て 90 秒間）炭酸ガスを吹き込み，その後 2 時間毎に 6 時間までの精子運動率および生存性を観察, 記録した。 その 結果, 融解後の精子生存性は 135 秒間以上の炭酸 ガスの処理で有意に低下した $(P<0.01)$ が, 90 秒以 内の処理時間では精子生存性の低下は認められなかっ た。

結論として, 90 秒以内の炭酸 ガス注入は融解後の精 子生存性に悪影響はなく, この制限時間内で炭酸ガスを 用いて迅速な非外科的子宮内人工授精が実施できるもの と思われる。 